\title{
Current Employability Scenario of Indian Graduates (Engineering, MBA \& Other Streams): A Review
}

\author{
Rajashree K. Gethe ${ }^{1}$, Mahesh S. Hulage ${ }^{2^{*}}$ \\ 1. Human Resource, Pune Institute of Business Management, Pune, India. \\ 2. Materials Management, Mahindra \& Mahindra Ltd., Pune, India.
}

*Corresponding Author: Mahesh S. Hulage

Abstract: Every Graduate Student dreams for a job with good salary once he receives Engineering and/or Management degree. But many of the graduates are not able to get an employment and those students who are getting the jobs they are being paid with less salary even after investing a lakh of money on their higher education. The general reason found behind this situation is a gap between what skills the industry/employers are expecting and what the skills graduate students are having with them. Today's Employers are looking for those candidates who are possessing wide range of Knowledge and Skills apart of conventional Degree. The present research paper discusses about the issues, concerns related to the Employability of Engineering and Management graduates. Paper also suggests some remedial actions to resolve the employment problems of the same students and promote the concept of Entrepreneurship where students will become 'Job giver' than 'Job seeker'.

Keywords: Employability skills, Engineering and MBA Graduates, Job market, Professional World.

\section{Introduction}

The purpose of this theoretical article is to address some issues of employability skills required by Engineering and MBA Graduates and to give some suggestions for improving their skills to make themselves 'Employable'.

This paper reviews drawbacks in existing Higher Education system and how it makes students only Degree based and not Skilled based job seeker which makes them incapable for getting job employment. Paper also discusses some serious problems and challenges currently facing by today's youth regarding skills and jobs.

In today's scenario, because of Globalization, Advancement in Technology industries are facing a tough competition in keeping and maintaining their existence and share in the market for which they immensely require a pool of candidate which are having high level of skills in order to meet changing market needs and wants. But as the time changes, market witnessed a radical shift in economic activities. Due to advancement in technology, nature of jobs, businesses, employment have been transformed.

In today's era, staying updated with technological advancements and rapid changes in surrounding are of prime importance for both success and growth of Individual and Business. = With each passing day, gap between actual skills and required skills by the market are widening and in order to fill this gap, companies are also adopting newer modes of recruitment to acquire the 'Skilled' Talents. And for attracting "Best Skilled talents" employers are focusing on Employer branding, Referrals, Data driven-recruiting using social media channels etc.

Employers all around the world are prominently looking for hiring the best talents. But still the gap between academic knowledge and the skills which are required professionally is widening because there is 
the lack of necessary skills which are required to meet the growing demands. Experts believe that this gap exists because many students though they have strong faith in their abilities, but very few people are able to make their passion as their career choice.

But because of family pressure, friend circles or some other reasons they don't want to take huge risk which occur while making lifechanging decisions about their career. Now-adays, it is very important for youth people to remain synchronized with the latest current trends and developments in the market. Also they need to upgrade their skills in order to create demand for themselves not just in India but globally.

In today's era, where there is a continuous change in the way that the companies are working, producing, communicating, interacting, it is very crucial for employees to remain aware with the changing demands, trends and developments in the market and upgrade their qualifications and skills accordingly. Thus, the key to meet market demands is 'reinventing'.

Process of reinventing means not only to explore newer work opportunities but also constantly exploring the opportunities which will promote mental and professional growth within existing environment. Companies in today's era are mostly preferring 'Talent Sourcing' through 'Referral platform'. With the time change, Companies are mostly opting for 'Recruitment Automation tools' which automate the process of recruitment where ATS (Application Tracking System), recruitment marketing software's are user friendly which makes process of finding, engaging, a pool of prospective candidates easy.

With the changing market situations, companies also giving emphasize on enhancing their interview techniques/ processes so as to meet objectives of recruitment and to maintain fairness and effectiveness of interview process. In past, Structured Interview was considered as obligatory norm for interviewer but now-adays, interviews are moved on to Unstructured (Casual) or Semi-Structured interviews.

The reason behind this change in recruitment process is Technological Advancement in job roles and Requirement of
Skill Based (in addition to Degree based) prospective candidates. A recent survey report by Aspiring Minds, over 80\% of the engineers are unemployable as they are lacking in technological skills as experienced by employers. Enhancing the skills is the long way path where Academic institutions plays a key important role of enhancing the skills of youth if they are adapting changing needs and wants of market. At present, current curriculum of almost of all universities is with $70 \%$ theoretical and 30\% practical knowledge which is the root cause behind why students are degree based but not skill based which has created obfuscation of skill development.

Due to increased requirement of skill personnel by corporate world, multiple qualifications, multiple degrees not able to help job seekers to get their dream job and role. But as per India's Skills Report, 2019 Engineers are continued to rule as the most employable among almost all professions. But Employability of MBA degree holders have fallen from $37.39 \%$ to $36.44 \%$ where both Engineering and MBA are the most popular degrees in India today [1-5].

\section{Literature Review}

Masura Rahmat et al. in their research paper titled "Relationship between Employability and Graduates Skill" found that there exists the relationship between employability and graduate's perception of their own skills. Thus the study suggests to whether the skills possessed by graduates during their studies are enough to helps them to get the job in the market. Confederation of British Industry [1] in its report found that companies are expecting graduates should have some desired/ expected skills and competencies which they can implement immediately in their job role once they are hired.

Because a number of students are pursuing higher education and professional qualifications for getting a job easily and with good salary. Clarke [2] in their study explains employability skills are the social aspect which should be treated at group level and not at an individual level. Clarke have the view that having employability skills is not just the whole and sole responsibility of the graduate alone but Universities, Institutes, Employers and Faculties should 
help graduates to learn and inculcate some employability skills in them in order to make them 'job getter' than 'job seeker'. Also Clarke [2] recommended that organization can do mentoring the newly hired graduates to learn and develop some employability skills in them once they are hired.

Adrian E. Stoics in her research paper "Development and Testing of a Comprehensive SK Framework for the Successful Employability of MBA Graduates". This study mainly focuses on conceptualizing and developing the Comprehensive Employability Skill Framework and to test in order to verify is there any perception gap exists between the groups surveyed regarding the most important skills which are required for the employability of MBA Graduates. Nidhi Pandey in her research paper entitled "Awareness of Life Skills for Job Sustainability Amongst Management Students".

The objective behind the study was to identify the important factors that are affecting on the employability of MBA Students. The study concluded that in order to get the job in today's competitive market, MBA Students needs to inculcate some additional skills and should develop critical thinking. Rajanibala J. Shah et al in their research paper entitled "A Study on Factors affecting Employability Skills of Management Students", the objective of the study was to study and understand the current scenario of market expectations for the management students and identify the factors which will fosters employability for them.

For analysis of collected data statistical tools like exploratory factor analysis and ANOVA were used. Findings of the study was Management students' needs to develop some analytical skills, self-understanding, general management understanding, adaptation with work culture, leadership skills, problem solving ability, improved oral and written English communication skills.

Saunders and Zuzel [3] in their research paper on Employability skills found that the interpersonal skills are the most preferred employability skills. Also it was found that while hiring a fresher candidate's employers are giving preference to core skills than technical skills. It also has been found that there should be the connection between industries required employability skills and curriculum teaching in the classroom in order to match the employability skills with the academic path of Graduate students. Archer and Davison [4] in their research study found that there was a difference in the skills that are offered by some universities and the actual requirement by the employers.

They also found that both small, medium and large scale companies are seeking for employability skills such as good/fluent English communication skills, some additional technical skills as per the job role and requirements.

Rubvita Chadha et al. in their research paper titled 'Industry's Requirement for Employability of Management Student in Present scenario". The main objective of this study was to identify and prioritize the various employability skills which are necessary for the management students for getting jobs. The study recommends that the management students' needs to learn some practical training of some required soft wares and some industrial exposure and learnings in order groom themselves for competing in the market for getting the job.

Also institutes should take some initiatives to invite experts from various industries so that students will interact with them which will helps students to develop confidence level, experts will share their industrial experiences and industry expectations from the fresher's which will helps in personality development of the students.

Asirvatham and Priya [5] in their research study found that employers are mainly seeking for basic abilities like computer skills, communication skills are needed for the employment. But further they also noted that many international companies prefer to employ those graduates who know foreign languages like German, French. Chinese where they are able to communicate with customers over the globe.

\section{Current Scenario of Higher Education in India:}

Below figure depicts the current higher education scenario in India. Where Higher education comes under the jurisdiction of Ministry of HRD (Human Resource Development). 


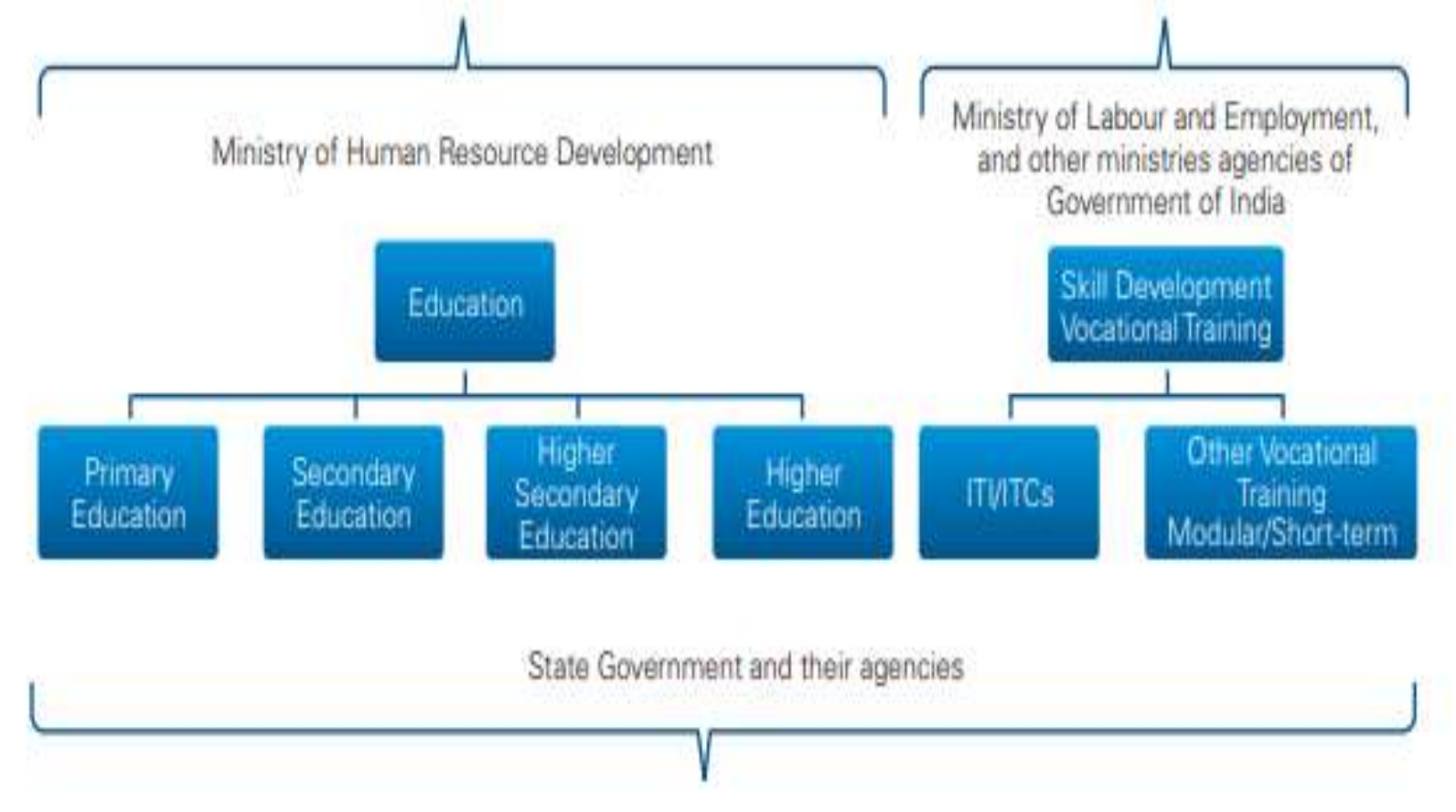

\section{Source: Human Resource and Skill Development in the Education and Skill Develooment Services Sector, NSDC}

Fig. 1: Education structure in India

\section{Current Employability Scenario of Indian Graduates (Engineering, MBA, any other Streams)}

Employability report revealed by Aspiring Minds for the year 2019, has clearly shown there is 'No Change or Improvement' in the employability of Indian Engineering graduates and this scenario persists since past 9 years. In case of MBA Students, Employability rate has been decreased from $41.02 \%$ to $36.44 \%$ from last 5 years as per the India Skills Report 2019.

For performing Engineering roles, cognitive and functional skills are enough but for employability in Management world, apart from cognitive and functional skills a complex mixture of personality traits and spoken and written communication skills are become of prime importance. Another noticing fact seen for employability of Engineering and MBA Graduates is that female's participation at work is considerably decreased from $29 \%$ to $25 \%$ since last 5 years.

Prominent reasons behind this drop down is, Impact of Maternity Benefits Act Amendment 2017 where employers needs to avail 26 weeks paid maternity leaves and benefits, also have to borne overheads for establishing infrastructure for crèche facility which is not affordable by the employer, also it have been observed that women's are having less flexibility at workplace as compared to male candidates as they have to stretched themselves for doing work at workplace and taking care of their family.

\section{Forces behind Remarkable Rise in Count of Degree Based than Skill Based Workforce}

India Skills Report 2019 says, by the year of 2022, the Indian workforce will be estimated to increase from current 473 million to approximately 600 million job seeker degree holder candidates. Major forces behind this increase in future job-seeker workforce are:

\section{Increase in Number of Degree Colleges}

Increased number of degree colleges for professional courses like Engineering, MBA and Pharmacy and so on. Research of National Employability report for Engineering Graduates 2019 found the fact that as the number of colleges in every state is goes on increasing the quantity of degree holder students in also goes on increasing out of which very few are having subject based and skilled knowledge who are capable of getting job in current competitive market. Also so many colleges are opened by politicians and under their political pressure they are securing easy approval from the All India Council for Technical Education [AICTE] to set up professional degree colleges of Engineering, Pharmacy, MBA, etc. 


\section{Selection/ Admission Procedure in Degree colleges}

As the number of colleges are goes on increasing, in order to fulfil the minimum intake of students which is mandated by government authorities, institutions are giving admissions to students at institute levels where students are on baseline of eligibility criteria where it teachers can give subject knowledge, can make students capable to pass interview process for any company but many of the students are failing to fulfil minimum eligibility criteria as prescribed by the Placement company.

\section{Lack of Quality Teaching}

Also some institutions, faculties are focusing on delivering subject knowledge, completing curriculum as per mandated by university and having very less or 'No' focus on improving skills of students because of which students are passing the exams for getting Degree and are not having practical skills which are very important for any job seeker to sustain in competitive market.

\section{Theory based Syllabus of Universities}

Many universities are having curriculum 70 $\%$ theory based and 30\% practical based knowledge which fail to fulfil corporate changing demands. (Source: Economic Times, 2019)

\section{Student's Self-interest}

Many students are completing their education and degree under the family pressure, or they entered into such degrees/professions where their interest is lacking. In such cases, for sake of completing the degree, students are attempting the exams, passing the exams and completing the education where they don't have any personal interest for self-improvement, making themselves capable for getting jobs.

\section{Lack of Corporate Involvement in Educational Activities}

Many Professional colleges and institutions from Tier I and Tier II levels are focusing on organizing various corporate events, programmes so as to give students overview of corporate experience, today's corporate demands and wants from youth so that students will inculcate necessary qualities in themselves so as to make themselves 'Employable'. But substantial size of employable population is generally from Tier
2 and Tier 3 institutions. But some of colleges are giving less priority and importance to such events. Also some colleges are not ensuring proper implementation of Industrial Internship and Training programmes but because of such lack of corporate involvement, corporate exposure students are not getting exposure of how to align theoretical concepts and knowledge while dealing with practical problems that are occurring in industries, how to make use of theoretical knowledge in practically.

\section{Reasons behind low Employability of today's Graduates}

According to an Associated Chambers of Commerce and Industry of India (ASSOCHAM) paper on "B-schools and Engineering colleges shut down- Big Business Struggles," revealed that since 2009, Campus recruitments at B-Schools have been reduced by $40 \%$. Below are some of the reasons for this low employability of Graduates from B-School in the recent years.

\section{Excess Supply of Degree holder Students}

In Indian Market, annual requirement for managerial candidates is generally between 35,000 to 40,000. But every year MBA's are graduating in lakhs. Annual Requirement for MBA is generally based upon the projection of 9 to $10 \%$ economic growth rate. But since past few years, economic growth was slowing down, because of which job opportunities for MBA's have not grown is the same proportion which leads to excess supply against low demand.

Also, as per the employability report 2017-18 revealed by ASSOCHAM, root cause behind rise in unemployed Engineering And MBA Graduates are many institutes are only focusing on filling up seats and do not consider the educational quality of students at the time of intake. Because of which many parents and students are rethinking on investing 3-4 years and several money in lakhs for the Engineering and MBA Course. As per the report of ASSOCHAM 2017-18, since 2015, more than 400 institutions and 250+ B-Schools are not getting enough students admissions to be remaining viable and run the institutes.

\section{Poor Quality of B-Schools:}

Government and AICTE are the sole bodies responsible for increasing the quantity of low 
quality business schools in the country. In many cases it has been found that government and AICTE have been given approval without examining or inspecting documents, infrastructure, faculty and many other basic requirements.

\section{Lack of Basic Skills in Students}

Major reason behind low employability of degree holders is that they are lacking in very basic skills which are of prime importance for getting the job in the today's competitive market. Many institutes are following university syllabus which is more theoretical than practical and also not focusing on improving the student's basic skills such as English Conversation/ Communication Skill, Maintaining Suitable Office attire, ability to apply theoretically learned concepts in practical experience, some soft skills and many more and lack of such basic skills in students drastically lower down their employability.

\section{Quality Faculty and Trainers}

Unfortunately, Many B-Schools in India failed to attract good quality teaching staff. Many of the faculties joins Engineering or Management institutions immediately after completion of their post-graduation where they are themselves lacking in Industrial experience and exposure because of which they are totally focusing on their teaching tasks such as session preparation, session delivery, Syllabus completion, Circulating Assignments, Assignment evaluations, Conducting exam and its evaluations but they are not taking additional efforts for improving the Students skills so as to make them capable to get the job in the market.

Also, in many of the institutions faculty members are not the permanent staff, Institute is hiring the faculties on ClockHour-Basis where visiting faculties are completely focusing on completion of syllabus only. Also they will be not available out of the class for resolving students study related problems. Many B-Schools are ignoring the need of retraining their faculties and also many of the faculties don't want to make the efforts for improving and updating their knowledge because of which they fails to make to employable graduates.

\section{Lesser Work Experience}

In USA and Europe, it is impossible to get an admission into good B-School without having some work experience. But in India, Many Students took admission to Post Graduation MBA program straight after graduation. Because of which though they are in postgraduation, it is expected that they should think 'Out of the Box' but unfortunately unlike teacher/faculties, students are also focusing on learning the theory and putting it in the paper at the time of examination and in this way they are completing their PostGraduation degree without any industrial exposure and experience.

\section{Slowdown of Economic Growth rate of India}

According to currently accepted versions of Okun's law, to achieve a one percentage point decline in the unemployment rate in the course of a year, real GDP must grow approximately 2 percentage points faster than the rate of growth of potential GDP over that period. So, for illustration, if the potential rate of GDP growth is $2 \%$, Okun's law says that GDP must grow at about a $4 \%$ rate for one year to achieve a one percentage point reduction in the rate of unemployment."

India's current economic growth rate is $5.8 \%$ in January-March period which is the slowest growth rate in last five years because of which unemployment rate rose to $6.1 \%$ in the 2017-18 fiscal years.

\section{What is Mean by Employability Skills?}

Employability is the ability of any graduate to get the job with the help of some required skills (Harvey, 2001). Employability skills are some basic skills which are necessary for getting, performing and maintaining job (Robinson, 2008). ASTD (American Society for Training and Development) prescribed 16 basic employability skills across all jobs are: reading, writing, speaking, listening, observing, quick learning creative thinking, goal setting, problem solving, career planning, teamwork, negotiation skills, leadership skills, understanding organization culture, ability to do more than one work at a time i.e. multitasking, ability to leverage technology etc.

Employability can be defined as, "An ability of job seeker to employ himself i.e. choosing a right career, having required knowledge, skills and abilities to perform the job and continuously improving self in order to perform job well. 
But now in today's market environment having only educational qualifications and possessing some required skills to perform the job is not sufficient but candidates should have some additional skills that are required by the employers.

\section{Framework for Skill Development}

Education is the key for development of human resource and it drives the economic growth of any country. But in today's competitive market environment, only
Education will not sufficient for economic growth but some vocational work/ training i.e. skill development become of prime importance for getting an employment. Currently there exists 3 tier institutional mechanism framework in the country with the Cabinet Committee on Skills at the Top, then National Skills Development Agency in mid which oversee and coordinate the efforts of various state government initiatives and the National Skill Development Corporation at the bottom.

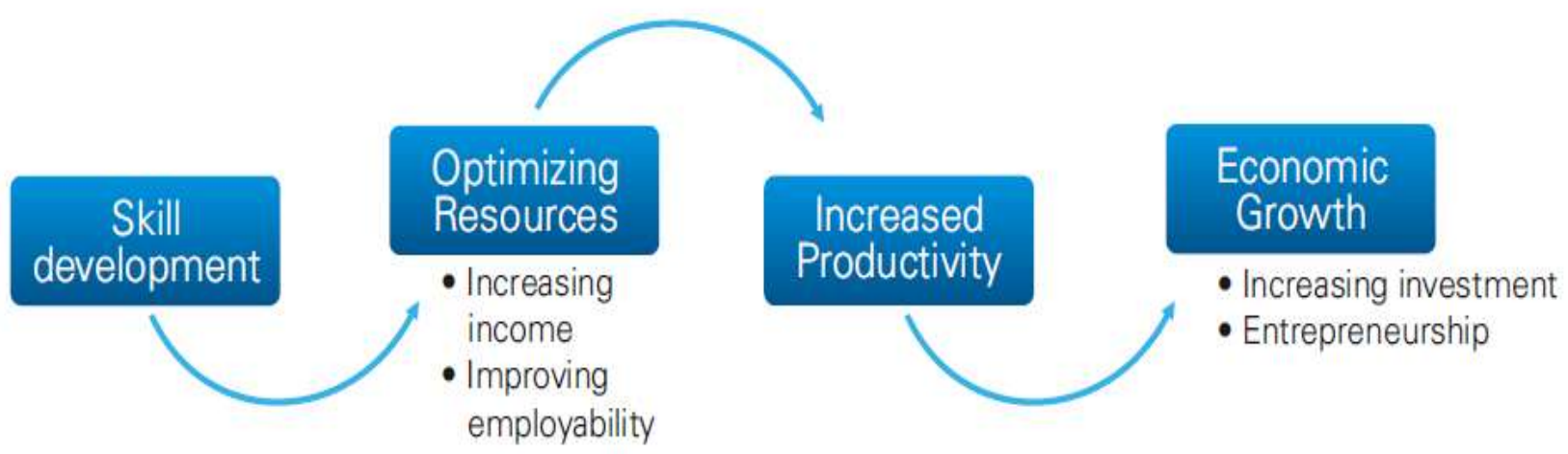

Fig. 2: Conceptual Framework for Skill Development

\section{Measures to be Taken by Engineering Institutes and B-Schools to Make their Students Employable}

\section{Updating Curriculum}

Various universities, Engineering institutes and B-Schools needs to reinvent their core syllabus and needs to update time to time with changing market requirement then and then only it will add value to both students and will make them employable. For this Institutes can upgrade their course structure by inviting experts from the industry to contribute some skill development, practical learning programmes which will help to improve the quality of Higher Education in India.

\section{Focus on Skill building}

Institutes and B-Schools should not neglect the significance of soft skills in improving the employability of their students. Institutes should take and implement some additional Aptitude; Communication training so that students will encourages to do some creative, critical thinking which will helps to build confidence level, improved Communication skills, interpersonal and leadership skills which in turn some inculcate employability skills in their students.

\section{Industrial Trainings and Internships}

According to Kulbhushan Saxena, Professor Emeritus at Fortune Institute of International Business, Industrial trainings and internships offers excellent way of connecting theoretical learnings with the practical exposure in real life and thus provides opportunity of experiential learning.

Thus, in classrooms students are getting Knowledge but through the Industrial Trainings and Internships Students encounter the real life complexities while doing the job, which gives them an opportunity to develop both Skills and Attitude to deal with the situation practically. Thus enhancing the employability skills of Fresh graduates though the exposure of Industrial Training and Internships become a key to their success in the corporate world.

\section{Re-train Faculty}

Faculties need to be undergoing continuously through trainings, Faculty development programmes which helps to re-train and update them in both theoretical and practical perspectives. Also faculties should be encourages to take some refresher courses, 
study breaks, participation in some industrial events to keep them updated with latest industry trends.

\section{Redesigning Teaching Pedagogy/ Tools}

Faculties should use some new methods of delivering sessions to students apart from traditional classroom teaching. Some incorporations of Study related Videos, Power presentations, Case lets/ CASE STUDY, Mini projects will make the sessions interactive and students will develop themselves not only in theoretical but also in practical perspectives.

\section{Reform College Examination Structure}

Faculties should not only focus on completion of syllabus and taking exam in traditional way i.e. writing the answers for the given questions. But faculties should inculcate some innovative ways of evaluation as follows:

\section{Presentations}

Faculty should assign students with some subject related / current topics and allowed students to prepare some PowerPoint presentations and give the presentations in front crowd of students which helps to reduce their stage fear and will build confidence to share their views in crowd and also it helps to improve communication and interaction skills.

\section{Case Study Solving}

Faculty should create/prepare some Case lets/ Case Study and should use as teaching pedagogy tool while delivering sessions. Case study helps the students to experience the practical problem (mentioned in the case) in the Classroom only. Thus Case Study helps to improve student's Critical thinking ability, Problem solving ability and Decision making ability.

\section{Multiple Choice Questions Tests}

Faculty wherever possible should include MCQ tests in their evaluations which helps students to pinpoint the learnings in shortest way. Thus MCQ Tests helps to improve logical thinking in students.

\section{Mini Projects}

Faculty should involve some subject related mini projects based on some practical learnings which helps to improve Creative Thinking ability of students.

\section{Interaction with Industry faces}

Institutes and B-Schools should organize some industrial events where peoples from Corporate world will interact with students, will share their views, real industry life problems that they are facing and current market demands and expectations from today's youth. It will surely help students to develop themselves with changing market/industry demands.

\section{Make Students Entrepreneurs not Employees}

With the interview of Times of India, Mr. T. N. Swaminathan said that B-schools should focus on developing Entrepreneurs i.e. students should inculcate an attitude of creating and providing a job and not becoming a job seeker.

\section{Interaction of Institutes with Industry}

The Employers, Industries and Academic bodies like ASSOCHAM, FICCI, CII, NASSCOM, NSDC, AIMA etc., should communicate sector and industry wise skill requirements to the institutes. Also some statutory bodies should make policies to encourage industrial and academia collaboration where institutes should interact with industry to get some insights about what type of skills they are expected from the fresher students and should call for some suggestions and recommendations which will helps to bridge the gaps between student's skills and industry requirements.

\section{Conclusion}

India already have been referred as a 'Knowledge Economy' by the World Bank with a vision India has maximum potential to achieve leadership in various sectors like IT, Healthcare, Science and Technology and many more. As per the survey conducted by 'University Search Engine India College Search', despite of struggling the Engineering institutes and B-Schools with falling intake of student admissions, suspect quality of course content and faculty, Engineering and MBA will remain one of the most preferred courses in India.

Because it is believed that both Engineering and MBA are the common man's entry ticket to get inside the world of industry and will give high profile job and salary which in turn will ensure better quality life i.e. in today's scenario we can call it as 'Financial Stability 
or Settlement of life'. But only becoming the 'Degree Holder' with a vast amount of theoretical knowledge with very little gain of key skills is not acceptable in today's competitive industrial market. Where industry is giving chance to those who are having a extra 'Skill Quotient' in addition to Educational Qualification. Thus upping a Skill Quotient is now become a need of an hour [6-20].

\section{References}

1. Confederation of British Industry (2008) Taking Stock. CBI Education and Skills Survey 2008. Available at www.cbi.org.uk/pdf/eduskills0408.pdf (accessed 28 January 2019)

2. Clarke M (2018) Rethinking graduate employability: The role of capital, individual attributes and context. Studies in Higher Education, 43(11): 1923-1937.

3. Saunders V, Zuzel K (2010) Evaluating Employability Skills: Employer and Student Perceptions. Bioscience Education, 15(1): 1-15. https://doi.org/10.3108/beej.15.2

4. Archer W, Davison J (2008) Graduate employability: What do employers think and want? The Council for Industry and Higher Education (CIHE) London. Available at www.cihe-

uk.com/docs/PUBS/0802Grademployability.pdf (Accessed 28 January, 2019)

5. Asirvatham IAS, Priya ML (2017) Employers Expectations on Employability Skills of Fresh Graduates -an Overview. International Journal of Innovative Research in Management Studies, 1(12): 15-18.

6. Pratap R (2017) Updated 2018). Worthless degrees and jobless graduates. Business line, The Hindu. Retrieved from: https://www.thehindubusinessline.com/news/ed ucation/worthless-degrees-and-joblessgraduates/article9660619.ece

7. The Economic Times (2016) Over 80 Per Cent Engineering Graduates in India Unemployable: Study. Retrieved from: https://economictimes.indiatimes.com/jobs/over -80-per-cent-engineering-graduates-in-indiaunemployablestudy/articleshow/50703662.cms?from $=m d r$

8. Ali FMA, Othman R, Ahmad B (2017) Graduate's Marketable Skills: An Empirical Investigation of Its Effect on Perceived Marketability of Yemeni Graduates in the Arab Gulf States.
9. Becker GS (1993) Human Capital: A Theoretical and Empirical Analysis with Special Reference to Education (3 ${ }^{\text {rd }}$ Ed.). Chicago: University of Chicago Press.

10. Bryman A (2017) Quantitative and qualitative research: further reflections on their integration. In Mixing methods: Qualitative and quantitative research (57-78). Routledge.

11. El Mansour B, Dean JC (2016) Employability skills as perceived by employers and university faculty in the fields of human resource development (HRD) for entry level graduate jobs. Journal of Human Resource and Sustainability Studies, 4(1): 39.

12. Marimuthu M, Arokiasamy L, Ismail M (2009) Human Capital Development \& Its Impact on Firm performance: Evidence from Developmental Economics. The Journal of International Social Research 8 summer.

13. Rajapakse RPCR (2016) Importance of soft skills in improving employability of graduates of National Universities in Sri Lanka-a literature search. EPRA International Journal of Research \& Development (IJRD), 1(9): 100103.

14. Yorke M (2006) Employability in Higher Education: What it is-What it is not? York: Higher Education Academy.

15. Skill Development and Higher Education in India, Report 2014.

16. "B and C Category B-schools producing unemployable pass-outs-Assocham India2016", URL:

http://www.assocham.org/newsdetail.php?id=5 651.

17. "93 per cent MBA graduates are unemployable: Problems with management education in India-2016",

http://indiatoday.intoday.in/education/story/mb a-educationproblems/1/712284.html.

18. "National Employability Report, MBA Graduates, Annual Report 2012" \& by Aspiring Minds,

http://www.aspiringminds.com/researcharticles/national-employabilityreport-mbagraduates-2012

19. "B-schools and Engineering colleges shut down-Big Business Struggles-2013", by ASSOCHAM.

20. Veesam Chandra Reddy (2016) Management Graduate Employability: Issues, Concerns and Suggestions, 6, 9 edn., International Journal of Research in Economics and Social Sciences (IJRESS): Thomson Reuters. 